\title{
O języku Akt Grodzieńskiego Sądu Ziemskiego
}

\author{
About the Language of Acts Grodno Zemstvo Court
}

Słowa klucze: Akta Grodzieńskiego Sq̨du Ziemskiego, Wileńska Komisja Archeograficzna, polonizmy, białoruskie gwary grodzieńskie

Key words: Acts of the Grodno Zemstuo Court, Vilna Archaeographic Commission, borrowings from the Polish language, Belarusian dialects of the Grodno region

\section{Wprowadzenie}

Akta Grodzieńskiego Sądu Ziemskiego ${ }^{1}$, będące przedmiotem niniejszego artykułu, ukazały się w 1890 roku jako 17. tom Akt publikowanych przez Wileńską Komisję Archeograficzną w latach 1885-1915². Jej działalność była związana z Wileńskim Archiwum Centralnym powołanym w 1852 roku do gromadzenia dawnych dokumentów. Sprowadzono tam 17767 ksiąg aktowych z różnych miejscowości następujących guberni: grodzieńskiej, kowieńskiej, mińskiej i wileńskiej (EnS, 1890: 262). Inicjatorem jej powołania był generał-gubernator Włodimir Nazimow. Działalność rozpoczęła się za rządów Michaiła Murawiowa, do współpracy zaproszono inspektora Wileńskiego Okręgu Szkolnego Iwana Korniłowa. Jako wzór posłużyła działająca już wówczas Kijowska Komisja Archeograficzna. Głównym zadaniem Wileńskiej Komisji Archeograficznej było tworzenie podstaw nowej historiografii terenów, które po rozbiorach stały się częścią Imperium Rosyjskiego, otrzymując nazwę Północno-Zachodniego Kraju (Северо-Западный край), zwłaszcza zaś udowodnienie wyłączności żywiołu ruskiego i prawosławia na ziemiach Wielkiego Księstwa Litewskiego. W tym celu prowadzono kwerendy $w$ archiwach i publikowano dokumenty historyczne pisane $w$ języku ruskim³. Wzmożona działalność Komisji wiązała się z klęską powstania styczniowego. W pierwszych latach swej działalności Komisja składała się z trzech osób: przewodniczącego i dwóch pracowników naukowych. Pracownicy kancelarii i kopiści byli zatrudniani przy

* e-mail: katarzyna.konczewska@ijp.pan.pl

1 Grodzieński Sąd Ziemski, powstały za czasów Zygmunta Starego, był jednym z najstarszych sądów ziemskich Wielkiego Księstwa Litewskiego.

2 Łącznie drukiem ukazało się 39 tomów Akt Wileńskiej Komisji Archeograficznej.

3 Według ówczesnej terminologii; we współczesnej literaturze przedmiotu jest on nazywany językiem starobiałoruskim lub zachodnioruskim. 
realizacji konkretnych zadań. Pierwszym przewodniczącym Komisji był doktor prawa Paweł Kukolnik, który po publikacji 1. tomu Akt odszedł na emeryturę ${ }^{4}$. Asystentami w pierwszych latach byli: Iwan Nikotin, kandydat prawa, Nikita Gorbaczewski, archiwariusz Wileńskiego Archiwum Centralnego, oraz Antoni Pszczołko, duchowny wileńskiej katedry prawosławnej. W 1870 roku w miejsce Iwana Nikotina przyszedł Siemion Szołkowicz, absolwent Uniwersytetu Kijowskiego, a w miejsce Antoniego Pszczołki - Iwan Sprogis, doświadczony archiwista, który w 1879 roku dostał posadę w Wileńskim Archiwum Centralnym5. Najpierw staraniem Komisji zostały opublikowane akta sądów grodzkich, ziemskich i podkomorskich Brześcia, Wilna i Grodna, a także akta Trybunału Litewskiego z okresu XVI-XVII wieku. Ponieważ po 1696 roku dokumenty urzędowe były pisane w języku polskim, w publikacjach Komisji po 1869 roku przed każdym dokumentem w języku polskim zamieszczano jego streszczenie rosyjskojęzyczne ${ }^{6}$.

Komisja współpracowała z licznymi instytucjami naukowymi Imperium Rosyjskiego, między innymi z Imperatorskim Towarzystwem Geograficznym, Imperatorskim Towarzystwem Miłośników Nauk Ścisłych i Przyrodniczych, Antropologii i Etnografii, Komisją Archeograficzną w Sankt Petersburgu, Komisją Archeograficzną w Kijowie, Archiwum Imperatorskiego Ministerstwa Sprawiedliwości w Moskwie.

Akta wydawane przez Wileńską Komisję Archeograficzną były rozsyłane do bibliotek na terenie całego Imperium Rosyjskiego, a bezpośrednio nabyć je można było w księgarni Abla Syrkina. Publikacje Komisji były zamawiane także przez inne księgarnie, a w Petersburgu Akta można było nabyć za pośrednictwem Imperatorskiej Akademii Nauk.

\section{Przedmiot i stan badań}

Przedmiotem niniejszego artykułu są Akta Grodzieńskiego Sądu Ziemskiego (dalej: Akta) zawarte w 17. tomie Akt Wileńskiej Komisji Archeograficznej wydanym w 1890 roku. Trzy pierwsze księgi Grodzieńskiego Sądu Ziemskiego z lat 1539, 1540 oraz 1541, przechowywane w Wileńskim Archiwum Centralnym pod numerami 6771, 6772 i 6773, zostały opublikowane w całości, natomiast z ksiąg z lat 1555-1565 wyekscerpowano tylko najciekawsze, zdaniem członków Komisji ${ }^{7}$, rozprawy. Akta są cennym materiałem nie tylko dlatego, że stanowią unikatowe źródło do badań $w$ zakresie historii Wielkiego Księstwa Litewskiego, panujących w nim stosunków ekonomicznych, stanu sądownictwa lub ówczesnych obyczajów. To także najstarsze dokumenty Wileńskiego Archiwum Centralnego pisane cyrylicą. Na potrzeby publikacji, według deklaracji wydawców, unowocześniono interpunkcję, natomiast zachowano oryginalną pisownię, co daje możliwość wieloaspektowych badań językoznawczych. Należy zwrócić uwagę na to, że Akta wydawane przez Wileńską Komisję Archeograficzną

${ }^{4}$ W kolejnych latach Komisji przewodniczyli: Piotr Bessonow, Jakub Gołowacki, Julian Kraczkowski, Flawian Dobrianski, Dymitr Dowgiałło.

${ }^{5}$ W różnych okresach członkami Komisji byli także: Wenedykt Płoszczanski, Iwan Glebow, Konstanty Snitko, Arseni Turcewicz, Aleksander Wrucewicz.

${ }^{6}$ Więcej o działalności Komisji zob. Not.roczn., 1914.

7 Do Komisji, składającej się wówczas z pięciu osób, należeli: Julian Kraczkowski, przewodniczący, Iwan Sprogis, Konstantin Snitko, Flawian Dobrianski, Wenedykt Płoszczanski. 
wzbudzały zainteresowanie przeważnie historyków. Zarówno w polskiej, jak i w białoruskiej literaturze przedmiotu brakuje opracowań dotyczących języka Akt grodzieńskich ${ }^{8}$. Poświęcił mu uwagę tylko Józef Trypućko ${ }^{9}$, wybierając wyrazy będące regionalizmami. Na podstawie tych notatek Zofia Kurzowa dokonała całościowej analizy materiału językowego zawartego w Aktach Wileńskiej Komisji Archeograficznej z okresu od XVI do XVIII wieku (KurzowA, 2006: 76-324), skupiając się przede wszystkim na rozwoju cech fonetycznych i gramatycznych.

Ponieważ tytułowe zagadnienie jest niezwykle szerokie, w niniejszym artykule przedstawię tylko wstępne ustalenia dotyczące strony językowej Akt w celu zapowiedzi głębszych badań nad tą problematyką i wskazania ich możliwych kierunków. Szczególną uwagę poświęcę wpływom polszczyzny na słownictwo Akt i funkcjonowaniu w nich żywej białoruskiej gwary grodzieńskiej ${ }^{10}$.

\section{Struktura}

Tom 17. Akt składa się z kilku części. We Wstępie (s. XXIII-LXXIII) zostały zamieszczone podstawowe informacje o publikowanych Aktach. Część główna zawiera w całości: pierwszą księgę Akt Grodzieńskiego Sądu Ziemskiego z lat 1539-1540 (s. 1-128; łącznie 312 akt), księgę drugą z lat 1540-1541 (s. 129-298; 456 akt) oraz trzecią z lat 1541-1542 (s. 299-396; 205 akt). Z akt lat późniejszych dokonano wypisów i zamieszczono (s. 397-444): z roku 1555 6 akt, z roku 1556 - 10 akt, z roku 1557 - 2 akta, z roku 1558 - 2 akta, z roku 1560 - 11 akt, z roku 1561 - 2 akta, z roku 1563 - 3 akta, z roku 1564 - 2 akta i z roku 1565 - 8 akt. Do publikacji dołączono indeksy imion (s. 445-505) i nazw geograficznych (s. 506-513) oraz słowniczek „przedmiotów i niektórych wyrazów przestarzałych” (s. 514-559).

\section{Osobliwości językowe}

Już w latach 30. XX wieku norweski slawista Christian Stang po dokonaniu szczegółowej analizy języka dokumentów Wielkiego Księstwa Litewskiego stwierdził, że poszczególne jego kancelarie: północne, z okolic Połocka, Witebska i Smoleńska, czy też kancelarie Witolda, Kazimierza Wielkiego, Aleksandra Jagiellończyka, Zygmunta Augusta - posługiwały się własną odmianą języka urzędowego (Żurawskı, 1978). Jednak podstawę wszystkich tych odmian stanowiły żywe gwary białoruskie, których leksyka czy też system gramatyczny były bliskie piśmiennictwa cerkiewnosłowiańskiego. Zwracał na to uwagę jeszcze Jefim

${ }^{8}$ Podczas gdy język szeroko pojmowanych dokumentów urzędowych Wielkiego Księstwa Litewskiego często był w centrum uwagi badaczy; przede wszystkim należy tu wymienić Statuty (LızısowA, $1980 ; 1984 ; 1999)$.

${ }^{9}$ Trypućko rozpisał pierwsze 9 tomów akt Wileńskiej Komisji Archeograficznej.

10 Białoruskie gwary grodzieńskie należą do grodzieńsko-baranowickiej grupy gwar języka białoruskiego. 
(Eustachy) KARSKı (1921: 9), który znał żywą gwarę białoruską z autopsji, ponieważ urodził się i wychował w miejscowości Łasza ${ }^{11}$ koło miasteczka Indura, blisko Grodna.

We Wstępie do Akt zaakcentowano, że głównym celem ich publikacji jest udowodnienie faktu, iż „Wielkie Księstwo Litewskie nie tylko miało mocne więzi z państwem rosyjskim, lecz także w znacznej części było zasiedlone przez ruski lud, święcie zachowujący swe starodawne ustawodawstwo, tradycje, nazwy ubrań, narzędzi, naczyń, budownictwa itd." ${ }^{12}$ (Akta, s. XXIII). Jednak członkowie Komisji, podkreślając, że język przedstawionych dokumentów jest „wyłącznie ruski”, zarazem przyznawali: „[...] chociaż ze znaczną domieszką form polskich" (Akta, s. XXIII). Jest to bardzo znacząca uwaga, rzucająca światło na ówczesne stosunki językowe $w$ Wielkim Księstwie Litewskim ${ }^{13}$, a jednocześnie pomocna w zrozumieniu sytuacji socjolingwistycznej na Grodzieńszczyźnie - nie tylko szesnastowiecznej, lecz także współczesnej.

Ścisła Grodzieńszczyzna (czyli teren dawnego powiatu grodzieńskiego istniejącego w latach 1413-1939) była dość specyficznym regionem: tu, na terenie pojaćwieskim, stykało się osadnictwo ruskie z mazurskim ${ }^{14}$, co miało swe odbicie na wszystkich płaszczyznach, również w warstwie językowej (SNIGIRova, 2014). Według Jana Feliksa Jakubowskiego, charakteryzującego terytorium powiatu $w$ XVI wieku, ówczesne nazwy geograficzne świadczą о „jednolitym, białoruskim charakterze ludności wiejskiej” (Jакивоwsкı, 1935: 102). Badacz zaznaczał, że jest na tym obszarze sporo nazw miejscowości mających brzmienie litewskie; zwracał także uwagę na osady drobnej szlachty o nazwiskach rodowych zarówno litewskich, jak i ruskich, w związku z czym określał skład etniczny „głównej, środkowej części powiatu jako mieszany litewsko-białoruski, z przewagą jednak liczebną elementu białoruskiego" (Jакивошsкı, 1935: 102-103). Podkreślał również, że już w XVI wieku nastąpiła całkowita asymilacja obu odłamów etnicznych, czyli językiem potocznym stał się język białoruski. Północną, „zapuszczańską” część powiatu (dawniej należącą do powiatu mereckiego; do grodzieńskiego przyłączoną w 1566 roku) zamieszkiwała ludność litewska, a położone nad granicą pruską osady zasiedlone były częściowo ludnością polską, mazurską. Ważna dla prowadzonych tu rozważań jest opinia Jakubowskiego na temat „elementu polskiego”, którego „na terenie powiatu spotykamy niewiele, jakkolwiek wpływ kultury polskiej zaznaczył się już bardzo wyraźnie, [...] język polski był już wówczas językiem potocznym klasy wyższej w powiecie, jak i w całym W. Księstwie Litewskim" (JAкUвоwsкı, 1935: 103). Leszek Bednarczuk w monografii Językowy obraz Wielkiego Księstwa Litewskiego przy omówieniu polszczyzny podlasko-grodzieńskiej stosuje $w$ odniesieniu do języka polskiego występującego na Grodzieńszczyźnie określenie „odmiana grodzieńska” (BEDNArczuK, 2010: 75-79, 84-87), zaznaczając, że zredagowane po polsku teksty pojawiają się na ziemi grodzieńskiej w końcu XVI wieku, a ich liczba w Aktach Grodzieńskiego Sqqdu Ziemskiego wzrasta w wiekach XVII-XVIII.

${ }^{11}$ We wsi do tej pory znajduje się cerkiew, w której pełnił służbę ojciec Karskiego, a biblioteka naukowa w Grodnie nosi imię Karskiego.

12 Tłumaczenia z dziewiętnastowiecznego rosyjskojęzycznego oryginału zostały wykonane przez autorkę artykułu.

13 Szczegółowo omówione przez Leszka Bednarczuka (2010).

14 Przebieg procesów osadnictwa na tych terenach szczegółowo opisał Jerzy WIŚNIEWSKI (1964; $1977 ; 1980)$. 
Prześledzenie funkcjonowania żywej białoruskiej gwary grodzieńskiej i wpływów polszczyzny w Aktach przedstawia się zatem jako bardzo interesujący problem badawczy. Ponieważ jest to zagadnienie złożone, $w$ niniejszym artykule przedstawię tylko wstępną próbę analizy (na podstawie subiektywnej ekscerpcji leksemów), by ukazać relację języka Akt do języków polskiego i białoruskiego oraz wskazać dalsze możliwe kierunki badań. Płaszczyzną porównawczą w zakresie gwar białoruskich uczynię wyłącznie słowniczek Apanasa Cychuna (SkCych) ${ }^{15}$, ponieważ inne słowniki gwarowe Grodzieńszczyzny ${ }^{16}$ zawierają leksykę całego obwodu grodzieńskiego, utworzonego dopiero w 1954 roku z różnych subregionów. Jako źródło leksyki historycznej zostały wykorzystane: Podręczny słownik historyczny leksyki substantywnej (SHist) pod redakcją Aleksandra Bułyki ${ }^{17}$ oraz Słownik staropolski (SStp) i Słownik polszczyzny XVI wieku (SPXVI) ${ }^{18}$. Ze względu na pokrewieństwo języków polskiego i białoruskiego oraz związane z tym podobieństwo strukturalne kwalifikowanie poszczególnych leksemów jako zapożyczeń polskich nie jest sprawą jednoznaczną. Z tego powodu wyekscerpowane wyrazy zostały sprawdzone w Słowniku etymologicznym języka polskiego Aleksandra Brücknera (SBr). Słownik ten, mimo pewnych niedostatków, jest jednak, według słów Zenona Klemensiewicza ze wstępu, „najlepszym słownikiem etymologicznym jednego ze słowiańskich języków", tym bardziej że wiele uwagi poświęcono w nim właśnie archaizmom.

\section{Słownictwo ${ }^{19}$}

Wśród wyekscerpowanych leksemów wytypowałam dwie podstawowe grupy:

5.1. Leksemy, które wyraźnie cechuje fonetyka i (albo) struktura polskich etymonów, nieposiadające cech właściwych gwarom białoruskim ${ }^{20}$ :

\section{блек’итный (s. 442): убранье люнское блекитное}

- SStp: błękitny; SPXVI: błękitny; SBr: błękitny z czesk. blankyt, w pol. z ę od XVI wieku; błrus.: блакітны;

15 Słownik ten zawiera miejscową leksykę gwarową wyłącznie z rejonu grodzieńskiego, niepoświadczoną w żadnym innym opracowaniu. W 2014 roku ukazało się jego drugie wydanie. W artykule korzystam z pierwszego akademickiego wydania z 1993 roku (pod redakcją Pawła Sciacko).

${ }^{16}$ Stan badań systemowych regionalnej białoruskiej leksyki Grodzieńszczyzny został omówiony m.in. w pracach: Ostrowski, 2013; KonczewsKA, 2016.

${ }_{17}$ Słownik ten powstał na podstawie kartoteki Słownika historycznego języka białoruskiego i uwzględnia leksykę używaną w okresie od XIV wieku do pocz. XVIII wieku, przede wszystkim $w$ funkcji komunikatywnej.

18 Jeżeli wyraz został zarejestrowany zarówno w SStp, jak i w SPXVI, wtedy w przypadku SPXVI sygnalizuję wyłącznie sam fakt poświadczenia.

${ }^{19}$ Wyekscerpowane leksemy podaję $w$ oryginalnej pisowni, w porządku alfabetycznym przyjętym dla alfabetu rosyjskiego. Akcent jest zaznaczony przed samogłoską akcentowaną. W nawiasach podaję stronę Akt.

20 Przyjmuję założenie Klemensiewicza, że zapożyczenia polskie „zdradzają się polską postacią fonetyczną, brakiem oparcia $w$ rodzimych rodzinach słowotwórczych, charakterem kalek" (KLEMENSIEWICZ, 1965: 159). 
вл'оскій (s. 407): сукня влоского сукна бурнатная изъ жеребьями серебреными

- SStp: włoski 'pochodzący z Włoch’; SPXVI: włoski; błrus.: італьянскі;

в'одлугъ (s. 22, 28, 33, 34, 35, 36, 40, 45, 52, 172): водлугъ права; водлугъ суда; водлугъ сведецьства; водлугв умовы

- SStp: według, z gen. rzeczownika 'wzór postępowania'; SPXVI: według; SBr: wedle; błrus.: паводле;

вонтпливый (s. 79): то есть речь не малая а вонтпливая

- SStp: wątpliwość 'brak pełnej wiary'; SPXVI: wątpliwy; SBr: wątpliwy; błrus.: сумніўны;

вш'акожь (s. 18, 43) / вщел'якожь (s. 53, 56, 80) / вщел'якая (s. 433): а вшакожъ я, абы Петку кривда не была; а вшелякожв для яснғйшого сведецьства; вшелякая речъ ку памети людской

- SStp: wszakoż, wszeliki; SPXVI: wszakoż; SBr: wszak, wszęgdy; błrus.: усяляк жа, усялякая;

д’исейший (s. 107, 124, 137, 309, 374): мяль дисейшого дня ставить свътка своего; дисейчого дня

- SStp: dzisiejszy 'bieżącego dnia lub czasu dotyczący'; SPXVI: dzisiejszy; SBr: dziś; błrus.: сённяшні;

дъдизна (s. 433): яко на властной дюдизне и отчизне своей

- SStp: dziedzistwo, dziedziszcze, dziedźnie 'mienie dziedziczone'; SPXVI: dziedzizna; błrus.: бацькаўшчьна; SHist: дедизна, дедызна, дедина 'дзедаўшчына';

жадный (s. 107, 267, 238 402): я не естемъ жадный отчичь пана ключниковъ; и жадное речи не знашли; не маючи на то жадного запису; жадного есми жита не браль

- SStp: żadny 'ani jeden, ani jakikolwiek'; SPXVI: żadny; SBr: żaden, niżadnyj; błrus.: аніякі;

загам'овать (s. 21, 53, 105, 112, 114, 146, 180, 182, 210, 237, 316, 335, 388, 417, 419): тоть брайцарь есми загамоваль

- SStp: hamować 'nie dopuszczać’; SPXVI: zahamować; SBr: zahamować [hasło hamować]; błrus.: затрымащчь;

звит'ежить (s. 432): ажебы тые ему помогли звитенжить неприятеля своего

- SStp: zwyciężać 'pokonywać, odnosić nad kimś zwycięstwo'; SBr: zwycięzca; błrus.: перамагчы;

звл'ащал/взл'аще (s. 10, 108, 268, 393, 398, 436): а звлаща, ижь шостый свътокъ пана; а взл'аще въ тоть обычай

- SStp: zwłaszcza, zwłaszcze ‘szczególnie, przede wszystkim'; SPXVI: zwłaszcza; błrus.: асабліва;

зост'авіць (s. 95): зоставиль ми шубъку китаичаную зеленую, брюшками лисьими подбитую

- SStp: zostawić ‘pozostawić coś komuś’; SPXVI zostawić; SBr: zostawić; błrus.: пакiнyųь; зуп'олный (s. 80): маючи отъ его милости зуполную моць

- SStp: zupełny, zupełni 'zawierający coś w wielkiej obfitości'; SPXVI: zupełny; SBr: zupełnie, od XVI wieku; błrus.: абсалютнь, цалкавіть;

им'аться (s. 30): и за подачки зъ тое части земли ся имали 
- SStp: imać się, imieć się 'posiadać, być właścicielem'; SPXVI: imać (się); SBr: imać od jąć; błrus.: мещ̧ųа;

капл'анъ (s. 51, 70, 197, 289): каплана святого Миколая, капланъ Городенский

- SStp: kapłan 'presbyter chrześcijański'; SPXVI: kapłan; SBr: kapłan od łac. capella przez czeskie kaplan; błrus.: святар, свяшчэннік; SHist: капланъ 'каталіцкі свяшчэннік'; клейн'оты (s. 409): забрали клейноты

- SStp: klejnot 'drogocenności'; SPXVI: klejnot/klenot; SBr: ze środkowoniemieckiego przez czeski klejnot; błrus.: каштоўнасці; SHist: клейнот 'каштоўнасці';

кревный (s. 402): тая кревная моя сама [...] продала

- SStp: krewny 'pochodzący z tego samego rodu'; SPXVI: krewny; SBr: krewny; błrus.: родзіч, кроўны; SHist: кровный 'сваяк па крыві';

малж'енство (s. 402): у малженство выдаль, у малженстве мешкаль

- SStp: małżeństwo 'związek zawarty między mężczyzną i kobietą zgodnie z prawem';

SPXVI: małżeństwo; SBr: małżeństwo z czes; błrus.: шлюб; SHist: малженство 'шлюб'; мпикать (s. 16, 42, 68, 90, 92, 100, 107, 127, 140, 149, 163, 203, 204): у вотияа моего мешкала; мпикали за отияомь нашим

- SStp: mieszkać 'przebywać gdzieś stale lub czasowo'; SPXVI: mieszkać; SBr: mieszkać; błrus.: жblų ${ }^{21}$;

надз'овать (s. 242): а я въ пашни надзоваль и робиль, якобы холопь

- SStp: nędza 'brak środków do życia, ubóstwo'; SPXVI: nędzować; SBr: nędzować; błrus.: жабраваць;

наз’аютрь (s. 41, 49, 64, 75, 90, 104, 115, 129): назаютрь присягнути готовь быль

- SStp: nazajutra 'nazajutrz, następnego dnia'; SPXVI: nazajutrz; SBr: nazajutrz; błrus.: паслязауттра;

нешп'орная (s. 34, 35, 54, 124, 137, 311): былъ пиленъ до нешпорныхъ годинъ; о нешпорной годинъ

- SStp: nieszporna godzina 'czas nieszporów'; SPXVI: nieszporny; SBr: nieszporny z czes. neszpor; błrus.: вячэрня; SHist: нешпорь 'вячэрня (у католікаў)';

очев'исте, очев'сто (s. 10, 16, 25, 27, 28, 30, 35, 37, 40, 46, 51, 56, 82, 94, 107, 148, 153, 203, 240): и поручиль очевисто три долги свои справяти; очевисте заручиль зарукою; и онъ ся къ тому очевисте призналь; стояли передъ нами очевисте

- SStp: oczywiste, oczywisto 'osobiście, we własnej osobie’; SPXVI: oczywisty; błrus.: сам, ва улласнай асобе;

п'евный (s. 91): а кгды будеть девка опекуна певного, то есть мужа мети

- SStp: pewny 'wzbudzający zaufanie'; SPXVI: pewny; SBr: pewny; błrus.: пэўны;

пл'ахта (s. 256, 413, 416, 442): а три плахты, а пять сорочокъ женскихъ; плахта Коленская, въ которой полотна три локти

- SStp: płachta 'duża chusta płócienna, kawał płótna używany do różnych celów'; SPXVI: płachta; SBr: płachta; błrus.: палотнішча; SHist: плахта 'палотнішча, намітка'; посп'ольный (s. 144, 332): тая сеножать за Соколдою есть нама зъ нимъ и зъ ьиншыми сябрями поспольная

- SStp: pospólny 'wspólny, wszystkich dotyczący'; SPXVI: pospolny; błrus.: супольнь;

${ }^{21}$ Zachował się jednak rzeczownik памямканне (mieszkanie). 
пренаг'абъе (s. 116): пасынокъ мой мъль отъ кого иного пренагабанье

- SStp: nagabanie 'prześladowanie, dręczenie'; SPXVI: nagabanie; SHist: пренагабанье 'турбота, турбаванне';

пр'осто (s. 366): оть угла кустовья кухарского просто межи земли Михна Тюдевича

- SStp: prosto 'na wprost, pionowo, dokładnie, bez świadków'; SPXVI: prosto; błrus.: прама, напрасткі;

р’ачить (s. 50, 55, 56, 113, 116, 240, 241): ее милость госпадарыня рачила дати князю; твоя милость рачиль узяти въ опгку

- SStp: raczyć 'zechcieć coś uczynić, kierując się łaskawością'; SPXVI: raczyć; błrus.: мець ласку;

р’оля (s. 157, 293, 359, 363, 372): ролю готовую взораную житомъ всеяли; зъ ролею тою, которую вжо быль поораль

- SStp: rola 'ziemia uprawna'; SPXVI: rola; SBr: rola; błrus.: ралля; SHist: ролья, ролия 'ралля, глеба, ворная зямля';

роск'азать (s. 16, 18, 33, 56, 57, 65, 123, 143): ямъ росказаль Миколаю сотнику; мы росказали есмо объма сторонамъ доводъ свой передъ нами поставити

- SStp: rozkazać 'polecić, zarządzić, powtórzyć czyjeś słowa'; SPXVI: rozkazać; błrus.: загадаиь;

p’ыхло (s. 353): какъ бы онъ могъ рыхло тыхъ светковъ передо мною поставити?

- SStp: rychło 'w szybkim tempie, w krótkim czasie'; SPXVI: rychło; SBr: rychło, zachodniosłowiańskie; błrus.: хутка;

тежь (s. 80): и видечи тежв тыхъ жидовъ подпальхх

- SStp: tė் 'tak samo'; SPXVI; SBr: też; błrus.: таксама;

турк'усъ (s. 313): одинъ съ туркусомъ каменемъ

- SStp: turkus 'kamień szlachetny niebieski lub niebieskozielony'; SPXVI: turkus; błrus.: біруза; SHist: туркусъ (туркосъ) 'біруза';

уф'ала (ухв'ала, вфала) (s. 170, 177, 187, 189, 232, 243, 272, 302, 330, 346, 349, 355, 362): ямъ тежъ на ухвалу права земъского обачивши; водълугъ уфалы правъ; водлугъ статуту и вфалы земской великого князьства литовского

- SStp: ufała 'postanowienie, orzeczenie'; SPXVI: uchwała; SHist: ухвала (вфала, уфала) 'пастанова';

фольг'овать (s. 107, 303): а нефолькгуючи никому свътчили; абы они жадной стороне не фолькгуючи справедливе до конща намъ тыи грани вказали

- SStp: folgować “ulegać, ustępować’; SPXVI: folgować; SHist: фолькгованье (фолгованье, фолкгование) 'палягчэнне, паслабленне';

фольдр'овать (s. 229, 240): не будуть на него передъ нами передъ правомь оть тоть разбой фольдровати; на кого бы они на имя о кгвалть свой фольдровали?

- SStp: fołdrować 'wystąpić z oskarżeniem'; SPXVI: fołdrować; SBr: fołdrować z niem. fordern; SHist: фольдровник 'абвінаваўца';

цехов'аный (s. 180, 181): если тая бочка цехована была; вжо тая соль цехована

- SStp: cecha 'znak służący jako dowód określonego uprawnienia, przynależności'; SPXVI: cechowany; SBr: cechować z niem. Zeichen; błrus.: nазначаны; SHist: цехъ ‘пячатка, знак'; 
ш'аты (s. 16, 337, 409): а шаты ей жь небожчика брата нашего ещче за живота своего далъ; иаты, зброі ваенныя

- SStp: szata ‘odzienie, odzież'; SBr: szata - „od nas na całą Ruś”; SHist: щama ‘плашч, вопратка'.

5.2. Leksemy poświadczone w Aktach oraz we współczesnych grodzieńskich gwarach białoruskich:

к'ульша (s. 412): у кульшу правую зъ луку прострелено

- SBr: kulsze 'biodra' od XVIII wieku, z lit. kulšis; białoruskie gwary grodzieńskie: к’ульша (SkCych): ‘бядровая частка нагі': У нашай Цащэлі вельмі тоўстыя кульшы; SHist: кульша (кулша); błrus. lit.: сияягно;

л'еха (s. 13): мають давати [...] на лень 4 лехи

- SStp: lecha 'zagon, grzęda'; SPXVI: lecha; SBr; białoruskie gwary grodzieńskie: л'exa (SkCych): 'кавалак ворнай зямлі': Цэлу леху зямлі захаniy; SHist: леха;

л'онскій (s. 288, 402): жита лонского и сеголетнего

- SStp: łoński 'zeszłoroczny'; SPXVI: łoński; SBr: łoński, słowiańskie, nie ma w litewskim; białoruskie gwary grodzieńskie: л’нскі (SkCych): Яны ашчэ лонскі хлеб ядуць, жыто маюиь старое; błrus. lit.: леташні;

мша (s. 142, 238, 309): въ суботу, по мши; на завтрее до мшей

- SStp: msza 'rodzaj nabożeństwa chrześcijańskiego, missa Christianorum'; SPXVI: msza; SBr: msza, z czeskiego; białoruskie gwary grodzieńskie: мша (SkCych): Мшу закупілі у касиелі па нібошчыку тату; SHist: мша; błrus. lit.: служба, rzadziej імша, w kościele katolickim;

мысл'івец (s. 238): съ тыми людьми и зъ мыслівцомь тымь

- SPXVI: myśliwiec; SBr: myślistwo, późny nabytek, wspólny z Czechami, wyraz nieznany innym Słowianom; białoruskie gwary grodzieńskie: мысл’iвеu (SkCych): Бblвае мыслівец праходзіцьь иеелы дзень $і$ з пустым дахаты ідзе; SHist: мысливецъ (мисливецъ); błrus. lit.: паляўнічы;

пуж'илно (s. 193, 239, 240): ямъ его пужилномъ вдариль; вдариль быль его по голове пужилномъ

- białoruskie gwary grodzieńskie: пуж’альнішча (SkCych): Найлепшае пужальнішчо гэта з ялаўиу; SHist: пужилно; błrus. lit.: пугаўё;

туб'ылец (s. 342): жадныхъ светковъ на то не маю, бо есми чужоземець, нетубылець

- SPXVI: tubylec; białoruskie gwary grodzieńskie: m’убалеu (SkCych): Ён лічыць себе тубальиам, бо даўно тут жыве; SHist: тубылецъ; błrus. lit.: мясиовы, тутэйшы;

фат'ыга (s. 192): вінен быль тоть Добко за фатыкги

- SPXVI: fatyga; SBr: z włos. fatica, łac. fatigare; białoruskie gwary grodzieńskie: фат’ыга (SkCych): Як кажуць, за дзянькуя ніи ні купя, за фат’ьıу трэбо заплаціиь, кап крыуды ні было; SHist: фатькка; błrus. lit.: клопать, турботыл. 


\section{Podsumowanie}

Akta Grodzieńskiego Sądu Ziemskiego są niezwykle cennym źródłem dostarczającym materiału do wielokierunkowych badań językoznawczych, w tym dialektologicznych, historycznojęzykowych bądź onomastycznych. Bardzo szeroko są w nich reprezentowane: toponimy ${ }^{22}$, mikrotoponimy i ojkonimy regionu, hydronimy, antroponimy oraz nazwy zawodów. $\mathrm{Na}$ szczególną uwagę zasługują zawarte w Aktach heortonimy, między innymi: Баг'ay/ Бог'атое, Вс'и Свит'ыи, Грамн'іиы, День Младени'овый, Зап'усты, Звъстов'анье, К'учки, Три Кр’ли, св. Малгор'ета/Маргор'ета, Навроч'енье св. Павла, Оферов'анье. Badania nad tą grupą tematyczną wydają się ciekawe nie tylko z punktu widzenia onomastyki, ale także z uwagi na możliwość wyciągnięcia nowych wniosków w zakresie współistnienia na Grodzieńszczyźnie różnych narodowości, kultur i religii. Interesujące byłoby też zestawienie nazwisk odnotowanych w rozprawach sądowych Akt z nazwiskami Списка вооруженным дворянам и татарам Гродненскаго повгта явившимся на смотр z 1765 roku, opublikowanego w 1874 roku w 7. tomie Akt wydanych przez Wileńską Komisję Archeograficzną. Pozwoliłoby ono na uzupełnienie historii grodzieńskich rodów szlacheckich i pomogłoby prześledzić ewentualne zmiany $w$ pisowni ich nazwisk rodowych. Na uwagę i dalsze badania zasługuje także fakt poświadczenia leksemów z XVI-wiecznych Akt we współczesnych białoruskich gwarach grodzieńskich wobec ich braku $w$ białoruskim języku literackim, co z jednej strony potwierdza tezę o żywych gwarach białoruskich jako podstawie języka urzędowego Wielkiego Księstwa Litewskiego, a z drugiej - wskazuje na archaiczność gwar grodzieńskich (por. KonczewsKA, 2018). Pogłębienie zasygnalizowanych w tym artykule badań, których celem jest porównanie języka Akt zarówno do języka polskiego, jak i białoruskiego, pozwoli prześledzić stopień wpływu języka polskiego na grodzieńską odmianę starobiałoruskiego języka urzędowego oraz skalę nasilenia tego wpływu w ciągu kilku następnych stuleci. Zwracają uwagę odnotowane $w$ artykule poświadczenia dość aktywnych wpływów polszczyzny już w pierwszych księgach Grodzieńskiego Sądu Ziemskiego, w 1. połowie XVI wieku. Warto zauważyć, że SHist poświadcza część polonizmów jako leksykę starobiałoruską wyłącznie na podstawie Akt, co wydaje się wątpliwe, ponieważ postać wyekscerpowanych w niniejszym artykule leksemów wskazuje wyraźną proweniencję polską. Zatem pogłębione, wieloaspektowe studium nad językiem Akt Grodzieńskiego Sądu Ziemskiego pozwoli na uzupełnienie pewnej luki w dotychczasowych badaniach językoznawczych - zarówno polskich, jak i białoruskich.

\section{Źródło}

Akta - Акты издаваемые Виленскою археографическою комиссіею (Akta wydane przez Wileńska Komisję Archeograficzną). T. 17: Aкты Гродненскаго земскаго суда (Akta Grodzieńskiego Sądu Ziemskiego). Wilno 1890 .

${ }^{22} \mathrm{~W}$ tym proces zmian nazwy miasta Grodno: Г’ородно - Городенъ (Гор'оденскій) - Гродна Гродно. 


\section{Słowniki}

EnS - АндРеЕвский И.Е., red., 1890: Энциклопедический словарь. Т. 2. Sankt Petersburg.

SBr - BRücKNER A., 1957: Słownik etymologiczny języka polskiego. Warszawa.

SHist - BuŁүкА A.M. (БулыкА А.М.), red., 2013: Падручны гістарычны слоўнік субстантыўнай лексікі. T. 1-2. Mińsk.

SkCych - Сүсниn A.P. (Цыхун А.П.), 1993: Скарбы народнай мовы. SсіАско Р. (Сцяцко П.), red. Grodno.

SPXVI - MAYenowa M.R. i inni, red., 1966-2018: Słownik polszczyzny XVI wieku. T. 1-37. Wrocław-Warszawa-Kraków.

SStp - URBAŃCZYK S., red., 1953-2002: Słownik staropolski. T. 1-11. Wrocław-Warszawa-Kraków.

\section{Literatura}

BednarczuK L., 2010: Językowy obraz Wielkiego Księstwa Litewskiego. Kraków.

Jakubowski J., 1935: Powiat grodzieński $w$ w. XVI (mapa z tekstem). W: Prace Komisji Atlasu Historycznego Polski. Z. 3. Kraków, s. 99-114.

КАRSKı E.F. (КАРский Е.Ф.), 1921: Белорусы. Т. 3: Очерки словесности белорусского племени. Ріоtrograd.

Klemensiewicz Z., 1965: Historia języka polskiego. Warszawa.

KONCZEWSKA K., 2016: Frazeologizmy i paremie białoruskich gwar grodzieńskich jako źródło rekonstrukcji obrazu świata mieszkańców wielonarodościowego regionu. W: RAK M., SıKoRA K., red.: Słowiańska frazeologia gwarowa. Kraków, s. 109-123.

KonCzeWsKa K., 2018: Archaizmy leksykalne współczesnej polszczyzny grodzieńskiej (socjolektu szlacheckiego). W: Pastuch M., Sıucıaк M., red.: Historia języka $w$ XXI wieku. Stan i perspektywy. Katowice, s. 355-367.

Kurzowa Z., 2006: Język polski Wileńszczyzny i Kresów północno-wschodnich XVI-XX w. Kraków.

Lızısowa M.T., 1980: Ze studiów nad słownictwem Statutu Wielkiego Księstwa Litewskiego. „Acta Baltico-Slavica" XIII, s. 37-65.

LızıSowA M.T., 1984: Studia nad słownictwem regionalnym III Statutu Wielkiego Księstwa Litewskiego. Kielce.

Lızısowa M.T., 1999: Język Statutów litewskich $w$ aspekcie kulturowym. „Acta Baltico-Slavica” XXIV, s. $229-238$.

Not.roczn., 1914: Пятидесятилетие Виленской Комиссии для разбора и издания древних актов: 1864 - 17 IV 1914. Юбилейная записка. Wilno.

Ostrowski B., 2013: Białoruskie gwary Grodzieńszczyzny. Wybrane zagadnienia. Kraków.

Snigirova N. (Снггірова Н.), 2014: Асаблівасці саџьылінгвістычнай сітуацыі у камунікатыуцай прасторы кантактнай зоны Беларусі і Польшчы (гістарычны аспект). „Socjolingwistyka” XXVIII, s. 109-120.

WiŚNIEWSKI J., 1964: Rozwój osadnictwa na pograniczu polsko-rusko-litewskim od końca XIV do połowy XVII wieku. „Acta Baltico-Slavica” I, s. 115-135.

WiśnIEWSKı J., 1977: Osadnictwo wschodniej Białostocczyzny, geneza, rozwój oraz zróżnicowanie i przemiany etniczne. „Acta Baltico-Slavica” XI, s. 7-80.

WIŚNIEWSKı J., 1980: Zarys dziejów osadnictwa na Białostocczyźnie. W: GLINKA S., OBRĘBSKA-JавŁońsкA A., Sıаткоwskı J., red.: Atlas gwar wschodniosłowiańskich Białostocczyzny. T. 1. Wrocław, s. 14-27. 
Katarzyna Konczewska

Żurawskı A.I. (Журавский А.И.), 1978: Деловая письменность в системе старобелорусского литературного языка. W: БЕЛОЗЕРЦЕВ Г.И., ИванОв В.В., ТРУБАЧЕВ О.Н., red.: Восточнославянское и общее языкознание. Moskwa, s. 185-191.

Katarzyna Konczewska

About the Language of Acts Grodno Zemstvo Court

Summary

This article, for the first time in scientific literature, presents comments about the language of documents of the Grodno Zemstuo Court, the oldest in the territory of the Grand Duchy of Lithuania. These documents were written in the $16^{\text {th }}$ century in Cyrillic and published in XVII vol. of the Act of the Vilna Archaeographic Commission. The article presents promising directions for the study of these documents, and special attention is paid to the impact on their vocabulary of the Polish language and the functioning of the Belarusian dialects of the Grodno region. 